\title{
I Lost my Son to Bullying: A Mother's Voice Speak Out
}

\section{Nasima Nastoh}

\section{Editor's Note:}

On April 22, 2002 I attended and presented a workshop on bullying at the Third Western Canada Symposium on child and teen violence. Called Caverns (Child and Adolescent Violence Education and Research Network Society) the symposium was supported by the Muttart Foundation, the Faculty of Social Work University of Calgary, Children's Mental Health Services and various other advocate and support care professional organizations.

At that conference I was privileged to meet Mrs. Nasima Nastoh who delivered a keynote address. Her talk invited participants to share in her story and penultimate grief. Mrs. Nastoh's son Hamid took his own life March 11, 2000. He jumped from the Pattullo Bridge because he was beleaguered and despondent about the constant taunting, harassment and intimidation he endured. Bullycide is a term used by some (Chodzinski, 2004) to describe child and teen suicide as it relates to bullying. It can be said that Hamid was bullied to death. Tragic outcomes related to severe bullying behaviour affect many individuals. Victims are not only those who are bullied but those who care for those who are bullied. They suffer the anguish and pain of knowing their loved one is bullied. In serious cases where tragic loss of life occurs the suffering is immeasurable.

What follows is Mrs. Hamid's message about her loss and about bullying. Mrs. Nastoh graciously permitted me to print her message as a tribute to all mothers who suffer as they struggle to manage the pain of knowing their child is being bullied at school. Her message is plain and appropriate for this issue on bullying in schools and communities. Bullying must stop. I urge everyone to read her address carefully and think about what you can do as an individual to proactively intervene in bullying behaviour.
Hamed Nastoh was born in Abbotsford. B.C December 18, 1985. He was the son of Nasima and Kirim Nastoh. They immigrated from Afghanistan in 1984 seeking a better and safer life in Canada. Hamid was known to be polite, kind, helpful and interested in school. According to his mother and family Hamid was a gentle boy who always showed respect and courtesy toward others. It was known that Hamid had been bullied at school, however, it seems that his teachers, his friends or his mother did not realize or anticipate the depth and seriousness of the violation and more important the devastating effect it had on Hamed. Despite Mrs. Nastoh's advice to Hamed to obtain counselling he, as in many other similar cases of bullying, chose to retreat, suffer in silence and eventually take desperate action. Two younger brothers, Abdullah and David live with the memory of their brother's short life.

It $\mathrm{t}$ is my pleasure to talk with you this morning about my son Hamed. He was a good boy who was bullied so much that he did not know what to do and so chose to take his own life on March 11, 2000. I cried very hard when I found out. In fact I screamed and called him to come to me and give me a big hug because I could not believe he was gone. I miss him so much. I lost Hamed because he was tortured and tormented by his schoolmates. I felt helpless, confused, sad, lost, and frustrated for a long time. I still do. My heart is broken forever but I decided to talk to you today hoping that perhaps by talking about Hamed and what happened to him it might help other mothers and other children who are suffering. I read to you a talk I gave to students and teachers at a Youth Forum called Diversity and Respect held Sunday, March 21, 2000. That day was called Hamed Nastoh's Anti-Bullying Day.

Who was Hamed? He led a torn and tormented life before committing suicide by jumping off the Pattullo bridge. Hamed took his own life after enduring relentless taunting by schoolmates. Bullies drove Hamed to death. Hamed threw himself from the Pattullo Bridge to his death after he was teased constantly at school. They called him gay, faggot, a geek and uncool. And they said it over and over again. Hamed was abused at school.

Conference delegates, bullying is a problem, a big problem in schools. Hamed drew cruel attention of a number of schoolmates who called him uncool, a geek and gay. They wrote faggot on his books. They followed him around the hallways and school grounds, taunting and teasing him. Hamed refused to retaliate. He tried to turn the other cheek. He refused to smoke or do drugs or anything else that would make him cool in the eyes of his tormenting peers.

The humiliation and rejection was tearing Hamed apart. Hamed was torn and tormented that he walked to the middle of Pattullo bridge over the Fraser river and cast himself into darkness.

Hamed left five pages of suicide note and asked that after his death I should go to every school and make kids aware that bullying has severe consequences and ask kids not to tease each other because it hurts deeply. Hamed wrote in his letter that he was crying inside but laughing outside.

He wrote in his letter "I could take a gun and shoot everyone who bullied me around but I am not a bad person and that is why $\mathrm{I}$ 
am taking my own life to show people how much I was hurting inside from being bullied." $\mathrm{He}$ wrote to the kids who bullied him around that "You know who you are and I am not gonna mention your names." Hamed was the type of a person that never complained and always kept it to himself.

As a mother, I have a message for bullies. I paid a very high price. Because of your teasing and bullying, I lost my beautiful son. I lost Hamed because of you. Hamed took his own life because you hurt him and never left him alone. You chased him around the school and wrote in his books that he was uncool and gay. You don't know how I feel. The loss that I am suffering is unbearable and there is a hole in my heart that can never be fixed. I miss Hamed. I call out to Hamed every morning to go to school. I set the table for him. I still buy his favourite food and I still play his favourite music. I kiss him every night as usual to say goodnight, but I kiss his picture, I scream in his room to talk to me but I cannot hear his voice. I am waiting for him to come back from school. Every morning I ask him to give me a hug but he doesn't listen to me. Why is he not responding to my voice? Why? The answer is clear: because of you bullies, because of you bullies - you tore and tormented him. I kept Hamed's dirty socks because it smells like Hamed. I don't want Hamed's smell to go away. I don't have anything against you bullies. I want no revenge, I love you because you are kids, and I love you because you have a mother too, and I do not want any mother to go through the same thing that I am going through. I whisper to Hamed all night please come back. To be honest, I have not accepted yet that Hamed is gone.

Hamed was well liked and loved by his friends, family and teachers. He was described as a talented young man who always worked hard, as loyal friend who was fun to be with and as someone who always tried to cheer people up. He always tried to cheer mommy up. I describe him as intelligent caring, kind and handsome.

The tragedy of Hamed's death teaches us that we must never underestimate the power of our actions. With one small gesture or one small phrase we can change a persons life for better, or for worse. I hope we will all look into our own soul to ask ourselves what we can do to prevent something like this from happening again. Let this be Hamed's legacy to us.

Please try hard to do something to prevent bullying and please think well of Hamed.

The original text of Mrs. Nastoh's message was first printed by OPTIONS (Services to Communites Society), Surrey, B.C. as a dedication to Hamed Nastoh in the report on the Youth Forum Diversity and Respect for All March 21, 2000, Surry, B.C.

\section{Top 10 Tips on how to beat the bullying!}

\section{Here are some ways to avoid being a victim of bullying} Tip \#1: Walk Tall

Try not to act scared. Practice 'walking tall' with shoulders back and head held high.

\section{Tip \#2: Develop Self-Confidence}

Be positive! Learn new skills. Get involved with people and activities that make you feel good about who you are. Remember, everyone is really good at something!

\section{Tip \#3: Start A School Program}

Make sure that your school has an anti-bullying program with tips on dealing with bullying incidents. If not, talk to your teacher or school principal about starting one. Hold staff and student meetings on a regular basis to review any issues.

\section{Tip \#4: Tell a Friend}

Always tell a friend or an adult you trust about the bullying. Having someone on your side will help you to stand up for your rights.

\section{Tip \#5: Walk Away}

If possible, ignore the bully or say "No" and walk away. The bully is seeking attention.

Tip \#6: Ignore The Teasing
Try not to react to the bullying and teasing. If you act like you don't care, the bully might get bored and give up.

\section{Tip \#7: Don't Fight Back}

The most dangerous thing you can do when confronted by a bully is to fight back. Bullies are generally stronger than their victims are. By fighting back, you could make matters worse.

\section{Tip \#8: Give Up Your Possessions}

If the situation is getting dangerous, if the bully is much bigger and stronger than you, or if he has a weapon, then it would be smart to give him what he wants. Material things are replaceable; you are not.

\section{Tip \#9: Stick With Others}

Try not to be alone in places where you could be unsafe - such as an empty schoolyard, a dark alleyway or a school washroom. If possible, try to stick with a group. Bullies tend to pick on those who are all alone.

Tip \#10: Remember, Bullies Have Weaknesses Too Like everyone else, bullies have weaknesses too. Try to see beyond the bully's scary face and words and think about what is missing in his like to make him act so cruelly

Give yourself a big pat on the back, if you use any one or more of these tips successfully.. 